\title{
Empirical Study on Sick Building Syndrome from Indoor Pollution in Nigeria
}

\author{
Adedeji O. Afolabi* ${ }^{*}$ Akpa Arome, Faith T. Akinbo \\ Department of Building Technology, Covenant University, Nigeria
}

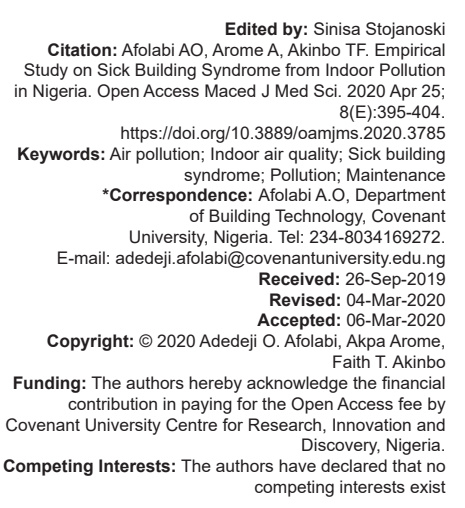

Introduction

In Maslow's hierarchy of man's needs proposed by Abraham Maslow in 1943, shelter is listed under the physiological need of man as the first out of five other needs of man [1]. Shelter serves as a place of rest and safety for people which should be carefully designed for their comfort. To achieve rest and safety, people spend about $90 \%$ of their time in buildings [2]. Several factors are usually considered in the design and construction of buildings to achieve maximum comfort and safety of the occupants such as ventilation, choice of materials, and the likes. When these factors which demand cognizance are not held in consideration during the production of buildings, they can be hazardous to the environment and the users in diverse ways. It has been witnessed, either through primary or secondary participation, the various negative effects buildings which were not properly designed and constructed have had on both the environment and their users. Instances such as building collapses, poor building materials in buildings have affected the health of the users and other related occurrences [3], [4]. It can be boldly stated, in light with popular perspectives, that buildings must be designed and constructed with an uncompromising consideration of the safety and well-being of the users in terms of the choice of materials (how the users will react to the materials health wise) and other constructional processes.

A significant percentage of workers in the private or public sector execute work in formidable office spaces (buildings), of which in most cases would have a central cooling and heating system, and windows that are seldom opened [5]. In these office spaces, several materials are used in the formation of working units in the likes of wallpapers and carpets, including equipment such as printers, computer screens, and photocopiers. The lighting system is usually not good because flickering neon lights are used. Furthermore, several chemical products are used for the maintenance and cleanness of the offices. All these compounds form the conditions that degrade the quality of the internal environment, and more generally, the internal climate of the buildings, with overt and important repercussions on both the mental and physical state of workers. Similar problems as these also arise in homes as well. In homes, the conditions for which cooking was carried out is very relevant. Some building occupants use coal and kerosene while some use gas. The fumes that are generated in the process if they are not well channeled outdoor or with proper ventilation systems can harm the occupants of the building. One of the formally-identified health effect which results from being exposed to indoor air contaminants is sick building syndrome (SBS). A myriad of symptoms 
signified the effects or presence of the SBS in occupants or users of buildings as well as the buildings themselves. The more the users or occupants of these buildings stay indoors, the more the symptoms persist [6]. However, when they exit the building for a while, these symptoms either subside or cease completely.

There are rising cases of building occupants with health-related challenges such as irritation, asthma, lung infections, headaches, and other allergies [7]. From the study by lyagba [7], it was shown that some of these health-related challenges are interconnected with attributes of the building they reside or work in. This may be aggravated with the presence of insects, rats, and other microbial organisms, indoor air pollution, as well as poor sanitary environments. A critical look at indoor air quality shows that Nigeria has been burdened with high fatalities (150 deaths per 100,000) attributed to air pollution based on the annual state of the Health Effects Institute [8]. Nigeria ranked $4^{\text {th }}$ globally among countries with the poorest air quality. The air quality can be attributed to both indoor and outdoor quality of building occupants. On the other hand, indoor air quality is negatively affected by the building fabrics, lack of ventilation, fumes from vehicles and generator fumes, indiscriminate burning, and cooking fumes. The unhealthy air quality has been attributed to the rising health challenges experienced in the eyes, lungs, and heart conditions of building occupants, including cancer. Therefore, this study was aimed at assessing SBS from indoor pollution in residential and office spaces with a view of highlighting probable solutions to reduce the effect of SBS on the occupants. The following objectives would guide this study, which are to;

Examine the symptoms associated with the SBS from indoor pollution in residential and office spaces

- Examine the indoor conditions that may be contributing to SBS in the residential and office spaces

- $\quad$ Evaluate the implication of SBS from indoor pollution on residential and office space occupants

$\bullet$

Measure the indoor pollutants contributing to the SBS among residential and office space occupants.

\section{Review of Related Literature}

According to Fotoula [9], the phenomenon "SBS" is a phrase which was first formed in the 1970s which is to delineate a state in when the occupants of a building suffer intense health challenges or a wide span of descriptions that include a collection of symptoms which surface when persons stay within certain buildings over a period of time. The World Health Organization [10] described SBS as a health situation in which persons in a building experience symptoms of sickness or feel temporarily ill with no clear cause. SBS ism a condition whereby building occupants suffer severe health issues and discomfort that are most probably influenced by the length of time spent within a building [11] The study in Sarafisa et al. [6] explained SBS as the range of symptoms on the well-being of a person that is identified with his/her stay in a building, which has a faulty interior condition quality. Subsequently, the term SBS is ordinarily utilized, so as to portray every one of those circumstances where the individual feels different symptoms or general bigotry and malaise and has no solid and distinguished disease that depicts these side effects. Some of these symptoms are itchy eyes, skin rashes, headache, dizziness, throat irritation, nausea, dry or itching skin, hoarseness of voice rashes, dry cough, allergy symptoms, and asthma attacks [7]. There are less obvious symptoms such as difficulty in concentration, fatigue, aches and pains, personality changes, and being sensitive to odors. The specified symptoms usually reduce or total seize after leaving the building, but the symptoms related to the skin and the skin being dry may take several days to fade out. When about $20 \%$ of individuals that work in a particular building have these symptoms and they vanish or decline significantly when employees leave the building, this can be a sign of SBS [12]. Most of the instances of SBS appears to be in buildings that run on automated heating systems, air-conditioning, and system ventilation, even though it can as well arise in commercial buildings such as Hospitals, Education institutes, and Schools an apartment building [9]. According to Zamani et al. [13], one of the popularly known health impacts resulting from the introduction of indoor air pollutants is SBS. SBS is a noteworthy concern as a significant number of people is possibly in danger. As characterized by the WHO (2010), it results into work-related disturbances of the mucous membranes and the skin and several possible symptoms such as headaches, fatigue, and difficulty with concentrating. The World Health Organization [14] evaluated that up to $30 \%$ of newly constructed and redesigned structures around the world might be identified with SBS. Complete investigation carried out in the UK on about 4373 office specialists in 42 open structures uncovered $29 \%$ of those considered experienced at least five of the trademark symptoms associated with SBS [15]. An examination of 600 office laborers in the USA inferred that $20 \%$ of the workers were experiencing SBS symptoms and this affected the work productivity of a large portion of them [5]. Moreover, an investigation on 1390 laborers in five open structures in Quebec, Canada, demonstrated that $50 \%$ of specialists experienced SBS symptoms [16]. In more recent times, SBS has turned into an issue of elevated concern in China, as large-scale construction of high-rise structures in metropolitan territories has prompted an unintended increase in building snugness. In an office high-rise, which was recently constructed in downtown Beijing, a dominant part of occupants lodged complaints relating 
to discomforts every day without clear causes. SBS was viewed as a feasible reason for this situation [17].

\section{Research Methods}

This section enumerates the research methods by which the study was carried out this study. It presents the step by step procedures through which data were collected and analyzed. In addition, it gives a brief geographical and historical background study of the study area so as to create a better understands of the topic. Cross-sectional survey research and experimental research design were used during the research to gather information. This was achieved through the distribution of questionnaires that were carefully constructed to ascertain the conditions prevalent in the population size. $A$ consent form was distributed alongside the questionnaire due to the nature of the research. While the experimental research survey design was executed through the use of a gadget called an air quality detector (produced by $\mathrm{Ou}$ Chuang Rui Technology), as shown in Figure 1. To carry out the experimental procedure in this research, the air quality detector was taken to locations within the area of study for on-ground measurement of the indoor air quality.

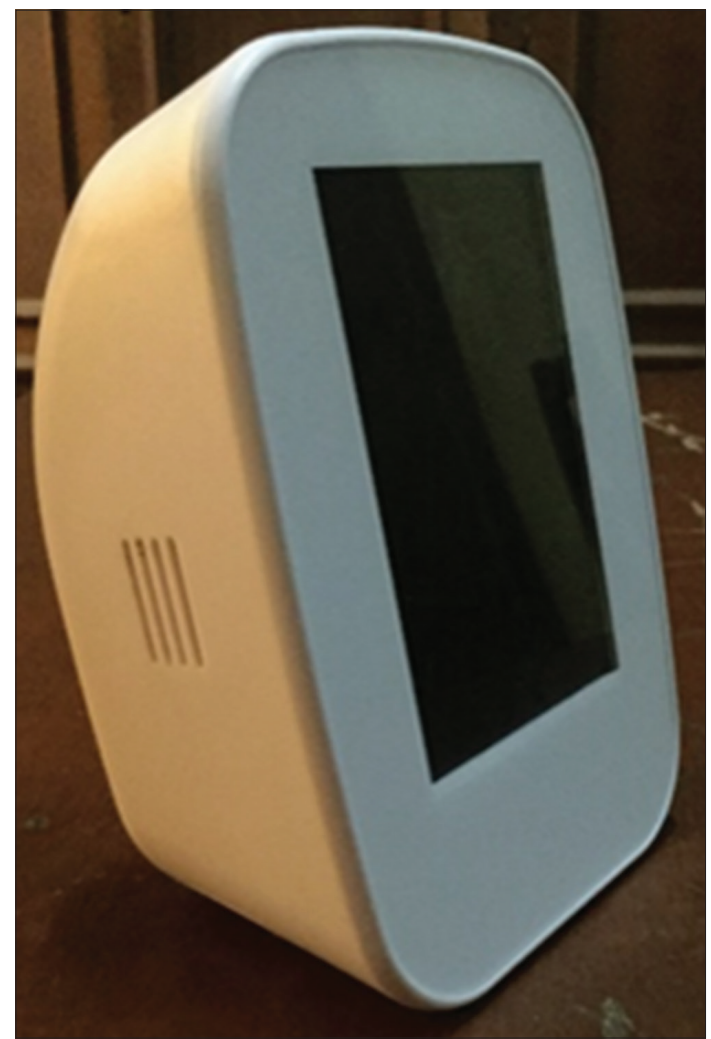

Figure 1: Air quality detector (produced by Ou Chuang Rui technology)

It is important to identify the actual population for the study. All buildings and office spaces within Nigeria form the population of the study. However, for the time frame of the study, buildings and offices within Kaduna State were chosen by the researchers. It includes house owners and tenants for residential and office users for the office environment. It is predominantly constituted of middle-class and more of lower-class citizens. The characteristics of the building owners and office space occupiers are people in different professions within the study area. Kaduna State is one of the 36 states in Nigeria that is located in Northern Nigeria. According to Health Effects Institute [8], Kaduna is listed amongst the top 10 most polluted places in Nigeria in terms of air pollution resulting from poor waste disposal and drain blockages. One of its local government, Zaria, was selected because it has a balanced mixture of urban and rural settlements. The area of study was scaled down to Samaru and the staff quarters in Ahmadu Bello University, both in Zaria, for houses while the Faculty of Agriculture in the same university was the study area for offices. From the population of residential and office spaces, the population was streamlined to an adequate sample size using the quota-purposive sampling technique and simple random sampling method. The quota-purposive sampling technique was used because there is no comprehensive data on the number of buildings in Kaduna at the time of this research. Therefore, a total of 60 residential buildings in the outskirt of the office spaces were selected. The formula used to obtain the sample size for the number of office spaces to be surveyed (using the air detector monitor) was a simple random sampling formula of;

$$
n=\frac{N}{1+\alpha^{2} N}
$$

Where; $\alpha$, confidence level $=0.05$

$\mathrm{N}$, total number of office spaces $=60$

$$
n=\frac{60}{1+(0.05)^{2} 60}=52
$$

There are presently 60 offices in the faculty of Agriculture, Ahmadu Bello University, which was ascertained through manual counting as the study area for offices. The sample size of 52 office spaces was calculated for the study, whereas only 51 office space users participated in this study. From the 60 residential buildings surveyed, only 49 occupants participated in the study.

This informed a balanced data collection from both residential and office buildings. The primary data in this study were obtained using a questionnaire instrument. It had four sections that were all aimed at assessing the buildings and perception of users in the buildings. Section $A$ of the questionnaire contains background information of the respondent. Section B is concerned with the symptoms experienced by the respondent while within the building. Section $C$ examined the indoor conditions available in the residential/office spaces. While Section D evaluated the implication of SPS from indoor pollution on the occupants. Furthermore, an air quality detector manufactured by Ou Chuang Rui technology was used in measuring the air quality in the residential and office 
spaces. Figure 2 showed a screenshot of a recording on the air quality detector device. In Figure 2, readings for $\mathrm{HCHO}$ (formaldehyde), $\mathrm{PM}_{2.5}$ (particle matter), $\mathrm{PM}_{10}$ (particle matter) total volatile organic compound (TVOC), temperature, and relative humidity were obtained.

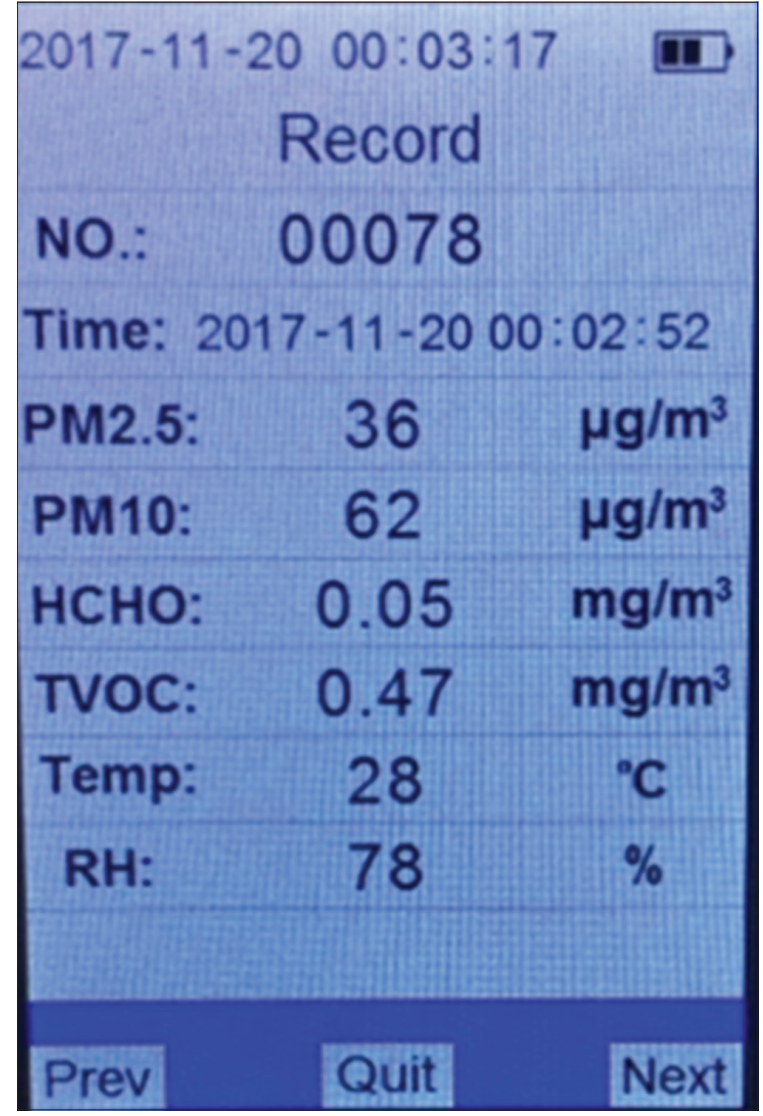

Figure 2: Screenshot of a recording on the air quality detector device

\section{Results and Discussion of Findings}

This section delineates the data analysis carried out on the data collected through the questionnaire survey and the readings from the indoor air quality detector. The questionnaires were given and collected from office and residential space users. The chapter shows a breakdown of the symptoms associated with SBS, the effects it has on the users of such buildings, and the probable factors that contribute it. The data collected were presented using percentages, pie chart, frequencies, bar chart, mean score, cross-tabulation, and ranking index.

\section{Background information}

In the course of this research, the respondents were selected randomly to participate in the survey. Table 1 showed a summary of the background information of the respondents in the study. The background information sought through the study includes the highest academic qualification, number of occupants in the buildings, gender, marital status, and duration of staying within the building. Table 1 showed that in the office space, under the highest qualifications, $1(1.96 \%)$ of respondents just had senior secondary certificate examinations (SSCE), 8 (15.69\%) were OND/HND holders, 20 (39.73\%) were B.Sc./B.Tech/B. Eng holders, 8 (15.69\%) were M.Sc./MBA/MPM/M. Tech holders, and 14 (27.45\%) were Ph.D. holders. While in residential spaces $15(30.61 \%)$ had just SSCE, $3(15.69 \%)$ were OND/HND holders, 18 (36.73\%) were B.Sc./B.Tech/B.Eng holders, 7 (14.29\%) were M.Sc./ MBA/MPM/M.Tech holders, and 6 (12.14\%) were Ph.D. holders. These results presented showed that the respondents were literate enough to have participated in the study. Table 1 also revealed that in the offices' spaces, 18 (35.29\%) of the offices were occupied by only one person, 20 (39.22\%) were occupied by two people, $4(7.84 \%)$ were occupied by three people, 3 $(5.88 \%)$ were occupied by four people, and $6(11.76 \%)$ were occupied above four people, while in residential spaces, $3(6.12 \%)$ were occupied by one person, 1 (2.04\%) were occupied by two people, 4 (8.16\%) were occupied by three people, 8 (16.33\%) were occupied by four people, and 33 (67.65\%) were occupied by above four people. Among the respondents in the office space, $34(66.6 \%)$ were males and $17(33.3 \%)$ were females whine in residential spaces, $25(51.0 \%)$ were male and $24(48.97 \%)$ were female. In the office spaces, 8 $(15.69 \%)$ had spent 1 year in that space, $9(17.65 \%)$ had spent 2 years, $5(9.80 \%)$ had spent 3 years, 1 $(1.96 \%)$ had spent 4 years, $2(3.91 \%)$ had spent 5 years, and $26(50.98 \%)$ had spent about 5 years, while in residential spaces, $8(16.33 \%)$ had spent 1 year in that space, $2(4.08 \%)$ had spent 2 years, $5(10.20 \%)$ had spent 3 years, 6 (12.24\%) had spent 4 years, 2 $(4.08 \%)$ had spent 5 years, and $26(50.98 \%)$ had spent above 5 years.

Table 1: Summary of background information

\begin{tabular}{llll}
\hline Background information & \multicolumn{2}{l}{ Type of building $(\%)$} & \multirow{2}{*}{ Total $(\%)$} \\
\cline { 2 - 3 } & Office space & Residential spaces & \\
\cline { 1 - 2 } Highest academic qualification attained & $1(1.96)$ & $15(30.61)$ & $16(0.16)$ \\
SSCE & $8(15.69)$ & $3(56.12)$ & $11(0.11)$ \\
OND/HND & $20(39.21)$ & $18(36.73)$ & $38(0.38)$ \\
B.Sc./B.Tech/B.Eng & $8(15.60)$ & $7(14.29)$ & $15(0.15)$ \\
M.Sc./MBA/MPM/M.Tech & $14(27.45)$ & $6(12.14)$ & $20(0.20)$ \\
Ph.D. & & & \\
Number of occupants & $18(35.29)$ & $3(6.12)$ & $21(0.21)$ \\
One & $20(39.22)$ & $1(2.04)$ & $21(0.21)$ \\
Two & $4(7.84)$ & $4(8.16)$ & $8(0.08)$ \\
Three & $3(5.88)$ & $8(16.33)$ & $11(0.11)$ \\
Four & $6(11.76)$ & $33(67.65)$ & $39(0.39)$ \\
Above four & & & \\
Gender of respondent & $34(66.6)$ & $25(51.0)$ & $59(0.59)$ \\
Male & $17(33.3)$ & $24(48.97)$ & $41(0.41)$ \\
Female & & & \\
Marital status & $40(78.43)$ & $19(38.78)$ & $59(0.59)$ \\
Married & $11(21.57)$ & $30(61.22)$ & $41(0.41)$ \\
Single & $8(15.69)$ & $8(16.33)$ & $16(0.16)$ \\
Period of stay in the building $(y e a r)$ & $2(4.08)$ & $11(0.11)$ \\
1 & $9(17.65)$ & $5(10.20)$ & $10(0.10)$ \\
2 & $5(9.80)$ & $6(12.24)$ & $7(0.07)$ \\
3 & $1(1.96)$ & $2(4.08)$ & $4(0.04)$ \\
4 & $2(3.91)$ & $26(50.98)$ & $52(0.52)$ \\
5 & $26(50.98)$ & & \\
Above 5 & &
\end{tabular}




\section{Symptoms associated with SBS}

This section highlighted the symptoms that occupants experience or suffer when using specific buildings under investigation. Table 2 showed the symptoms associated with SBS either for residential and office space users. The presence or absence of the 22 highlighted symptoms was indicated by the respondents and analyzed using a 4-point Likert scale with "Always $=4$ ", "Sometimes $=3$," "Rarely $=2$," and "Never = 1." The symptoms associated with SBS were identified from previous studies in Atarodi et al. [18].

Table 2: Symptoms associated with sick building syndrome

\begin{tabular}{|c|c|c|c|c|c|c|}
\hline \multirow[t]{2}{*}{ Symptoms } & \multicolumn{2}{|c|}{ Residential apartment } & \multicolumn{2}{|c|}{ Office spaces } & \multirow[t]{2}{*}{ Overall MS } & \multirow[t]{2}{*}{ Overall RI } \\
\hline & $\overline{\mathrm{MS}}$ & $\mathrm{RI}$ & $\overline{\mathrm{MS}}$ & $\mathrm{RI}$ & & \\
\hline Symptoms of cold or flu & 2.22 & $5^{\text {th }}$ & 2.43 & $1^{\text {st }}$ & 2.32 & $1^{\text {st }}$ \\
\hline Weakness & 2.35 & $1^{\text {st }}$ & 2.14 & $3^{\text {rd }}$ & 2.24 & $2^{\text {nd }}$ \\
\hline Burning or nasal itching & 2.22 & $5^{\text {th }}$ & 2.10 & $4^{\text {th }}$ & 2.16 & $3^{\text {rd }}$ \\
\hline $\begin{array}{l}\text { Muscle pain in arm or } \\
\text { hand }\end{array}$ & 2.31 & $2^{\text {nd }}$ & 2.02 & $9^{\text {th }}$ & 2.16 & $3^{\text {rd }}$ \\
\hline $\begin{array}{l}\text { Feeling cold in the hands } \\
\text { or feet }\end{array}$ & 2.31 & $2^{\text {nd }}$ & 2.00 & $11^{\text {th }}$ & 2.15 & $5^{\text {th }}$ \\
\hline Feeling heavy air & 2.24 & $4^{\text {th }}$ & 2.04 & $7^{\text {th }}$ & 2.14 & $6^{\text {th }}$ \\
\hline $\begin{array}{l}\text { Chest pain or chest } \\
\text { tightness }\end{array}$ & 2.22 & $5^{\text {th }}$ & 2.06 & $6^{\text {th }}$ & 2.14 & $6^{\text {th }}$ \\
\hline Back pain & 2.12 & $8^{\text {th }}$ & 2.16 & $2^{\text {nd }}$ & 2.14 & $6^{\text {th }}$ \\
\hline Itching the eyes & 2.12 & $8^{\text {th }}$ & 2.10 & $4^{\text {th }}$ & 2.11 & $9^{\text {th }}$ \\
\hline Fatigue & 2.04 & $12^{\text {th }}$ & 2.04 & $7^{\text {th }}$ & 2.04 & $10^{\text {th }}$ \\
\hline Respiratory problems & 2.08 & $11^{\text {th }}$ & 1.96 & $12^{\text {th }}$ & 2.02 & $11^{\text {th }}$ \\
\hline Nervousness & 2.00 & $13^{\text {th }}$ & 2.02 & $9^{\text {th }}$ & 2.00 & $12^{\text {th }}$ \\
\hline $\begin{array}{l}\text { Itching, swelling, or } \\
\text { dry skin }\end{array}$ & 1.98 & $15^{\text {th }}$ & 1.96 & $12^{\text {th }}$ & 1.97 & $13^{\text {th }}$ \\
\hline Burning or sore throat & 1.98 & $15^{\text {th }}$ & 1.94 & $14^{\text {th }}$ & 1.96 & $14^{\text {th }}$ \\
\hline Depression & 1.92 & $19^{\text {th }}$ & 1.92 & $15^{\text {th }}$ & 1.92 & $15^{\text {th }}$ \\
\hline Neck pain & 2.10 & $10^{\text {th }}$ & 1.73 & $21^{\text {st }}$ & 1.91 & $16^{\text {th }}$ \\
\hline Dizziness & 2.00 & $13^{\text {th }}$ & 1.80 & $18^{\text {th }}$ & 1.90 & $17^{\text {th }}$ \\
\hline Drowsiness & 1.96 & $17^{\text {th }}$ & 1.82 & $16^{\text {th }}$ & 1.89 & $18^{\text {th }}$ \\
\hline $\begin{array}{l}\text { Problem with vision/ } \\
\text { blurred vision }\end{array}$ & 1.86 & $21^{\text {st }}$ & 1.82 & $16^{\text {th }}$ & 1.84 & $19^{\text {th }}$ \\
\hline Nausea & 1.94 & $18^{\text {th }}$ & 1.75 & $20^{\text {th }}$ & 1.84 & $19^{\text {th }}$ \\
\hline Headache & 1.88 & $20^{\text {th }}$ & 1.76 & $19^{\text {th }}$ & 1.82 & $21^{\mathrm{st}}$ \\
\hline Fever & 1.69 & $22^{\text {nd }}$ & 1.67 & $22^{\text {nd }}$ & 1.68 & $22^{\text {nd }}$ \\
\hline
\end{tabular}

In Table 2, the study showed that among residential occupants, the main symptoms associated with SBS were major signs of weakness, muscle pain in arm or hand, feeling cold in the hands or feet, and feeling heavy air. Among office space users, the main symptoms include cold or flu, back pain, and weakness. The overall mean score showed that the building occupants mostly felt symptoms of cold or flu, weakness, burning or nasal itching, and muscle pain in the arm or hand. Therefore, the study showed that cold or flu, weakness, burning or nasal itching, and muscle pain in arm or hand are symptoms of SBS that both residential and office space users mostly experience. Even though the symptoms ranked between "sometimes" and "rarely," they are still significant in that occupants have in one time or the other felt SBS, which inhabiting their residential or workspace. This study is corroborated by findings from Atarodi et al. [18]. In that, most of the symptoms identified in this study are similar to the findings in their study. Most of the respondents faced symptoms associated with discomfort reported in lyagba [7] as mucus membrane irritation which affects the nose and other respiratory parts. The study by Gomzi and Bobic [12] reported that over $40 \%$ of the persons surveyed reported having headaches, stuffy nose, and fatigue in relation to SBS.

\section{Indoor conditions of the building spaces}

This section evaluated the indoor conditions of residential and office spaces with respect to several necessary features and functions that should be available. Table 3 revealed the indoor conditions of the residential and office spaces that were surveyed during this study. The conditions were indicated by the respondents and analyzed using a 5-point Likert scale with "Very Convenient $=5$," "Appropriate $=4, "$ "Normal $=3$," "Inappropriate $=2$," and "Very Inappropriate $=1$. ."

Table 3: Indoor conditions of residential and office spaces

\begin{tabular}{|c|c|c|c|c|c|c|}
\hline \multirow[t]{2}{*}{ Indoor condition } & \multicolumn{2}{|c|}{ Residential apartment } & \multicolumn{2}{|c|}{ Office space } & \multirow{2}{*}{$\begin{array}{l}\text { Overall } \\
\text { MS }\end{array}$} & \multirow{2}{*}{$\begin{array}{l}\text { Overall } \\
\text { RI }\end{array}$} \\
\hline & $\overline{\mathrm{MS}}$ & $\mathrm{RI}$ & $\overline{\mathrm{MS}}$ & $\mathrm{RI}$ & & \\
\hline Lighting conditions & 3.57 & $6^{\text {th }}$ & 4.12 & $1^{\text {st }}$ & 3.85 & $1^{\text {st }}$ \\
\hline Headroom in the building & 3.67 & $2^{\text {nd }}$ & 3.96 & $2^{\text {nd }}$ & 3.82 & $2^{\text {nd }}$ \\
\hline Position of the windows & 3.78 & $1^{\text {st }}$ & 3.84 & $7^{\text {th }}$ & 3.81 & $3^{\text {rd }}$ \\
\hline Size of the windows & 3.67 & $3^{\text {rd }}$ & 3.88 & $4^{\text {th }}$ & 3.78 & $4^{\text {th }}$ \\
\hline Ventilation & 3.67 & $3^{\text {rd }}$ & 3.86 & $6^{\text {th }}$ & 3.77 & $5^{\text {th }}$ \\
\hline Size of the doors & 3.67 & $3^{\text {rd }}$ & 3.76 & $11^{\text {th }}$ & 3.72 & $6^{\text {th }}$ \\
\hline Color of walls & 3.57 & $6^{\text {th }}$ & 3.82 & $8^{\text {th }}$ & 3.70 & $7^{\text {th }}$ \\
\hline Size of the room spaces & 3.39 & $9^{\text {th }}$ & 3.90 & $3^{\text {rd }}$ & 3.65 & $8^{\text {th }}$ \\
\hline Noise level & 3.53 & $8^{\text {th }}$ & 3.63 & $15^{\text {th }}$ & 3.58 & $9^{\text {th }}$ \\
\hline Curtains & 3.33 & $10^{\text {th }}$ & 3.75 & $12^{\text {th }}$ & 3.54 & $10^{\text {th }}$ \\
\hline Maintenance of facilities & 3.20 & $11^{\text {th }}$ & 3.82 & $8^{\text {th }}$ & 3.52 & $11^{\text {th }}$ \\
\hline Odor & 3.04 & $15^{\text {th }}$ & 3.88 & $5^{\text {th }}$ & 3.47 & $12^{\text {th }}$ \\
\hline Air conditioning system & 3.14 & $13^{\text {th }}$ & 3.75 & $12^{\text {th }}$ & 3.45 & $13^{\text {th }}$ \\
\hline Smoke & 3.02 & $16^{\text {th }}$ & 3.78 & $10^{\text {th }}$ & 3.41 & $14^{\text {th }}$ \\
\hline Congestion/overcrowding & 3.18 & $12^{\text {th }}$ & 3.55 & $16^{\text {th }}$ & 3.37 & $15^{\text {th }}$ \\
\hline The heat & 2.96 & $17^{\text {th }}$ & 3.67 & $14^{\text {th }}$ & 3.32 & $16^{\text {th }}$ \\
\hline The cold & 3.06 & $14^{\text {th }}$ & 3.47 & $17^{\text {th }}$ & 3.27 & $17^{\text {th }}$ \\
\hline
\end{tabular}

From Table 3, most of the indoor conditions within the buildings were normal. In the residential spaces, the indoor conditions occupants were most comfortable with was the position of the windows, the headroom in the building, the size of the windows, ventilation, and the size of the doors. In the office spaces, occupants were most comfortable with the lighting conditions, headroom in the building, and the size of the windows. Overall, occupants were comfortable with lighting conditions, headroom in the building, and the position of the windows. The findings from this study showed that the visual and working environment is mostly affected by the indoor conditions prevalent within the buildings studied. lyagba [7] noted that once lighting, headroom, and windows are poor within a living or working space, it forces a strain on the eye which can lead to headaches and other SBS. Furthermore, the study posits that some indoor conditions could spur SBSs. The hypothesis was put forward for testing that;

$\mathrm{H}_{01}$ - There is no relationship between specific indoor conditions and identified SBSs.

$\mathrm{H}_{1}$ - There is a relationship between specific indoor conditions and identified SBSs.

The study used a spearman rho's correlation matrix to understand the relationship between specific indoor conditions and SBSs. Table 4 showed the correlation matrix between indoor conditions within the offices and residential spaces and the SBSs identified in the study. Using the significant value of $0.05 p$-value, Table 4 showed relationships that exist between indoor conditions and SBS within the surveyed area. In Table 4, there was a significant relationship between occupants' having headaches and fever with indoor conditions 
such as the use of air conditioning systems and increased noise level. This corroborated in the study by Fotoula [9], where it was affirmed that there is a need to provide a protective measure toward reducing noise pollution and a review of cleaning practices in homes and offices. This can be achieved through concerted efforts in educating occupants and active legislation to tackle these pollutants. Furthermore, there was a significant relationship between drowsiness and lighting conditions and weakness and size of the room spaces. Gomzi and Bobic [12] referred to the issues of lighting conditions affecting an occupant's health as a building factor because individuals may have limited control over the lighting conditions within a building.

\section{Implications of SBS}

This section was concerned about the implications of SBS on the health of the residential and office space users. Table 5 presented the implications of SBS experienced by the respondents. The implications were analyzed using the respondents and analyzed using a 5-point Likert scale with "Very High = 5," "High $=4$," "Moderate = 3," "Low = 2," and "Nil = 1."

From Table 5, among the residential occupants, SBS can lead to a need to change residential/office space, fatigue, and high irritation. While, among office space users, the major consequences of SBS were mostly increased maintenance needs, dizziness, and depression/ breakdown. The overall mean score among the residential and office space users showed that SBS can lead to increased maintenance needs, dizziness, and depression/ breakdown. A further inferential statistical test was carried out to ascertain if there were significant implications as a result of SBS on occupants in the buildings surveyed. The hypothesis put forward tested that;

$\mathrm{H}_{02}$ - There is no difference in the implication of SBS on both office space users and residential apartment occupants.

$\mathrm{H}_{2}$ - There is a difference in the implication of SBS on both office space users and residential apartment occupants.

The study tested hypothesis two using analysis of variance (ANOVA) to measure the significant difference that exists in the implication of SBS. Table 6 showed the ANOVA test on the implications of SBS on office and residential occupants. Using the type of occupants as the factor and the implication of SBS as the dependent list, the ANOVA test was conducted. The decision rule of when $p<0.05$, the alternate hypothesis is accepted and the null hypothesis is rejected and this applies vice-versa. Therefore, in Table 6, the significant implications of SBS are that SBS can lead to stress, can reduce productivity, can affect concentration, can lead

Table 4: Correlation matrix on indoor conditions and SBSs

\begin{tabular}{|c|c|c|c|c|c|}
\hline $\begin{array}{l}\text { Indoor conditions } \\
\text { Sick building syndrome }\end{array}$ & Lighting conditions & Ventilation & Size of the room spaces & Air conditioning system & Noise level \\
\hline Headache & -0.159 & -0.090 & -0.162 & $-0.240^{*}$ & $-0.283^{\star *}$ \\
\hline Fever & -0.059 & -0.004 & -0.109 & $-0.237^{\star}$ & $-0.241^{*}$ \\
\hline Dizziness & 0.038 & -0.042 & -0.128 & -0.066 & -0.071 \\
\hline Fatigue & 0.118 & 0.076 & -0.096 & -0.092 & 0.003 \\
\hline Drowsiness & $0.201^{*}$ & 0.176 & 0.002 & 0.106 & 0.141 \\
\hline Weakness & -0.027 & -0.127 & $-0.273^{\star *}$ & -0.038 & -0.117 \\
\hline Nausea & -0.017 & -0.080 & -0.041 & -0.159 & 0.049 \\
\hline Respiratory problems & -0.027 & -0.019 & -0.096 & -0.049 & 0.035 \\
\hline Muscle pain, arm, or hand & -0.132 & -0.068 & -0.151 & -0.076 & -0.016 \\
\hline Chest pain or chest tightness & 0.037 & -0.029 & -0.093 & -0.034 & -0.009 \\
\hline Back pain & -0.069 & -0.027 & -0.152 & 0.057 & -0.069 \\
\hline Itching the eyes & 0.147 & 0.190 & -0.085 & 0.052 & 0.076 \\
\hline Neck pain & -0.084 & -0.043 & -0.038 & 0.012 & -0.029 \\
\hline Problem with vision/blurred vision & 0.058 & 0.006 & -0.024 & 0.011 & -0.089 \\
\hline Burning or sore throat & 0.187 & 0.138 & 0.139 & 0.060 & 0.078 \\
\hline Burning or nasal itching & 0.067 & -0.003 & 0.001 & -0.077 & 0.016 \\
\hline Symptoms of cold or flu & 0.039 & -0.042 & 0.006 & -0.075 & -0.110 \\
\hline Depression & 0.029 & -0.021 & -0.114 & -0.064 & -0.009 \\
\hline Nervousness & 0.025 & -0.061 & 0.000 & -0.073 & -0.063 \\
\hline Itching, swelling or dry skin & -0.022 & -0.019 & -0.126 & -0.168 & -0.049 \\
\hline Feeling cold in hand or feet & -0.025 & 0.081 & -0.083 & -0.143 & -0.017 \\
\hline Feeling heavy air & 0.108 & 0.055 & -0.193 & -0.051 & 0.037 \\
\hline
\end{tabular}

${ }^{* *}$ Correlation is significant at the 0.01 level (2-tailed) ${ }^{*}$ Correlation is significant at the 0.05 level (2-tailed).

Table 5: Implications of sick building syndrome

\begin{tabular}{|c|c|c|c|c|c|c|}
\hline \multirow[t]{2}{*}{ Implications } & \multicolumn{2}{|c|}{ Residential apartment } & \multicolumn{2}{|c|}{ Office space } & \multirow[t]{2}{*}{ Overall MS } & \multirow[t]{2}{*}{ Overall RI } \\
\hline & MS & RI & MS & $\mathrm{RI}$ & & \\
\hline Increased maintenance needs & 2.39 & $11^{\text {th }}$ & 2.47 & $1^{\text {st }}$ & 2.70 & $1^{\text {st }}$ \\
\hline Dizziness & 2.51 & $6^{\text {th }}$ & 2.33 & $2^{\text {nd }}$ & 2.42 & $2^{\text {nd }}$ \\
\hline Depression/breakdown & 2.55 & $4^{\text {th }}$ & 2.25 & $3^{\text {rd }}$ & 2.40 & $3^{\text {rd }}$ \\
\hline Need to change residential/office space & 2.73 & $1^{\text {st }}$ & 2.02 & $7^{\text {th }}$ & 2.37 & $4^{\text {th }}$ \\
\hline High irritation & 2.57 & $3^{\text {rd }}$ & 2.12 & $5^{\text {th }}$ & 2.34 & $5^{\text {th }}$ \\
\hline Poor breathing & 2.39 & $11^{\text {th }}$ & 2.25 & $3^{\text {rd }}$ & 2.32 & $6^{\text {th }}$ \\
\hline Reduced commitment & 2.53 & $5^{\text {th }}$ & 2.10 & $6^{\text {th }}$ & 2.31 & $7^{\text {th }}$ \\
\hline Fatigue & 2.58 & $2^{\text {nd }}$ & 2.02 & $7^{\text {th }}$ & 2.29 & $8^{\text {th }}$ \\
\hline Loss of appetite & 2.47 & $8^{\text {th }}$ & 1.98 & $10^{\text {th }}$ & 2.22 & $9^{\text {th }}$ \\
\hline Can lead to stress & 2.49 & $7^{\text {th }}$ & 1.92 & $12^{\text {th }}$ & 2.20 & $10^{\text {th }}$ \\
\hline Frequent illness (headache, etc.) & 2.35 & $13^{\text {th }}$ & 2.02 & $7^{\text {th }}$ & 2.18 & $11^{\text {th }}$ \\
\hline Reduced productivity & 2.45 & $10^{\text {th }}$ & 1.90 & $13^{\text {th }}$ & 2.17 & $12^{\text {th }}$ \\
\hline Loss of sleep & 2.35 & $14^{\text {th }}$ & 1.96 & $11^{\text {th }}$ & 2.15 & $13^{\text {th }}$ \\
\hline Loss of concentration & 2.41 & $9^{\text {th }}$ & 1.80 & $15^{\text {th }}$ & 2.10 & $14^{\text {th }}$ \\
\hline Health challenges & 2.29 & $15^{\text {th }}$ & 1.84 & $14^{\text {th }}$ & 2.06 & $15^{\text {th }}$ \\
\hline
\end{tabular}


to the need to change residential/office space, reduced commitment, and increased need for maintenance works. These findings are supported by Joshi [11] in that SBS affects the productivity of workers and would increase absenteeism amongst workers.

Table 6: ANOVA test on the implications of sick building syndrome

\begin{tabular}{|c|c|c|c|c|c|}
\hline Implications & $\begin{array}{l}\text { Sum of } \\
\text { squares }\end{array}$ & df & $\begin{array}{l}\text { Mean } \\
\text { square }\end{array}$ & $\mathrm{F}$ & Sig. \\
\hline \multicolumn{6}{|l|}{ Can lead to stress } \\
\hline Between groups & 8.069 & 1 & 8.069 & \multirow[t]{3}{*}{4.944} & \multirow[t]{3}{*}{0.028} \\
\hline Within groups & 159.931 & 98 & 1.632 & & \\
\hline Total & 168.000 & 99 & & & \\
\hline \multicolumn{6}{|l|}{ Reduced productivity } \\
\hline Between groups & 7.478 & 1 & 7.478 & \multirow[t]{3}{*}{5.138} & \multirow[t]{3}{*}{0.026} \\
\hline Within groups & 142.632 & 98 & 1.455 & & \\
\hline Total & 150.110 & 99 & & & \\
\hline \multicolumn{6}{|l|}{ Health challenges } \\
\hline Between groups & 4.895 & 1 & 4.895 & \multirow[t]{3}{*}{3.845} & \multirow[t]{3}{*}{0.053} \\
\hline Within groups & 124.745 & 98 & 1.273 & & \\
\hline Total & 129.640 & 99 & & & \\
\hline \multicolumn{6}{|l|}{ Loss of concentration } \\
\hline Between groups & 9.124 & 1 & 9.124 & \multirow[t]{3}{*}{8.777} & \multirow[t]{3}{*}{0.004} \\
\hline Within groups & 101.876 & 98 & 1.040 & & \\
\hline Total & 111.000 & 99 & & & \\
\hline \multicolumn{6}{|l|}{ Fatigue } \\
\hline Between groups & 7.858 & 1 & 7.858 & \multirow[t]{3}{*}{8.409} & \multirow[t]{3}{*}{0.005} \\
\hline Within groups & 90.647 & 97 & 0.935 & & \\
\hline Total & 98.505 & 98 & & & \\
\hline \multicolumn{6}{|c|}{ Frequent illness (headaches etc.) } \\
\hline Between groups & 2.678 & 1 & 2.678 & 2.260 & 0.136 \\
\hline Within groups & 116.082 & 98 & 1.185 & & \\
\hline Total & 118.760 & 99 & & & \\
\hline Need to change resi & & & & & \\
\hline Between groups & 12.779 & 1 & 12.779 & 8.431 & 0.005 \\
\hline Within groups & 148.531 & 98 & 1.516 & & \\
\hline Total & 161.310 & 99 & & & \\
\hline Reduced commitme & & & & & \\
\hline Between groups & 4.676 & 1 & 4.676 & 4.550 & 0.035 \\
\hline Within groups & 100.714 & 98 & 1.028 & & \\
\hline Total & 105.390 & 99 & & & \\
\hline Loss of sleep & & & & & \\
\hline Between groups & 3.726 & 1 & 3.726 & 3.121 & 0.080 \\
\hline Within groups & 117.024 & 98 & 1.194 & & \\
\hline Total & 120.750 & 99 & & & \\
\hline High irritation & & & & & \\
\hline Between groups & 5.146 & 1 & 5.146 & 3.841 & 0.053 \\
\hline Within groups & 131.294 & 98 & 1.340 & & \\
\hline Total & 136.440 & 99 & & & \\
\hline Poor breathing & & & & & \\
\hline Between groups & 0.441 & 1 & 0.441 & 0.286 & 0.594 \\
\hline Within groups & 151.319 & 98 & 1.544 & & \\
\hline Total & 151.760 & 99 & & & \\
\hline Increased maintenar & & & & & \\
\hline Between groups & 5.478 & 1 & 5.478 & 3.961 & 0.049 \\
\hline Within groups & 135.522 & 98 & 1.383 & & \\
\hline Total & 141.000 & 99 & & & \\
\hline Depression/breakdo & & & & & \\
\hline Between groups & 2.191 & 1 & 2.191 & 1.654 & 0.201 \\
\hline Within groups & 129.809 & 98 & 1.325 & & \\
\hline Total & 132.000 & 99 & & & \\
\hline Dizziness & & & & & \\
\hline Between groups & 0.782 & 1 & 0.782 & 0.582 & 0.447 \\
\hline Within groups & 131.578 & 98 & 1.343 & & \\
\hline Total & 132.360 & 99 & & & \\
\hline Loss of appetite & & & & & \\
\hline Between groups & 5.976 & 1 & 5.976 & 3.633 & 0.060 \\
\hline Within groups & 161.184 & 98 & 1.645 & & \\
\hline Total & 167.160 & 99 & & & \\
\hline
\end{tabular}

\section{Indoor pollutants contributing to the SBS}

The air quality monitor was used to obtain the readings of certain air particles that can lead to SBS. The particles that the air quality monitor read were

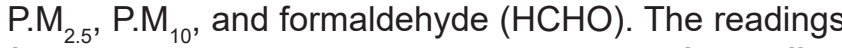
for the temperature and relative humidity of the office and residential spaces visited during this survey were taken. According to the World Health Organization [19], the 24-h mean standard for $\mathrm{PM}_{2.5}$ is $25 \mu \mathrm{g} / \mathrm{m}^{3}$. $\mathrm{PM}_{2.5}$ is a fine particulate matter usually referred to as air pollutants due to the fact that they have been found to have a close link with heart and lung diseases such as asthma, bronchitis, and other respiratory problems. Figure 3 showed a chart generated from the readings of particles, $\mathrm{PM}_{2.5}$ obtained from thirty-five (35) offices space, and thirty-five (35) residential spaces in comparison to the standard reading from the World Health Organization (WHO).

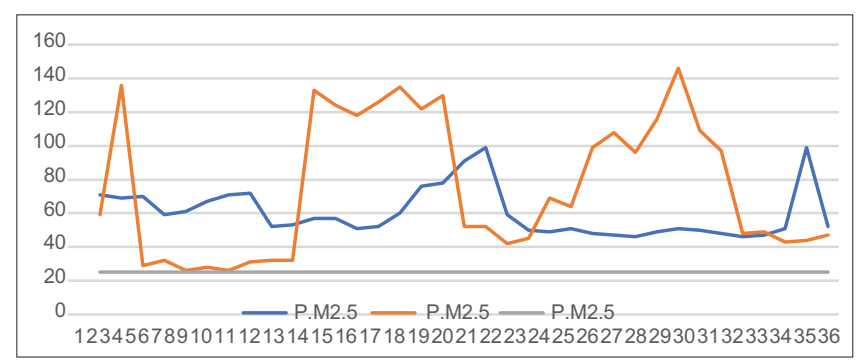

Figure 3: Measurement of particles, P.M 2.5

The 24-h mean for $\mathrm{PM}_{2.5}$ was $75.57 \mu \mathrm{g} / \mathrm{m}^{3}$ and $60.26 \mu \mathrm{g} / \mathrm{m}^{3}$ for the residential spaces and office spaces, respectively. From Figure 3, only two residential spaces came close to the WHO standard for 24-h mean standard for $\mathrm{PM}_{2.5}$ while the other spaces for both the office and residential spaces were clearly above the standard for $\mathrm{PM}_{2.5}$. Therefore, it can be concluded from the results in the chart that $\mathrm{PM}_{2.5}$ was unhealthy in most of the offices and residential spaces. Whereas, $\mathrm{PM}_{10}$ is a more coarse particle with $10 \mu \mathrm{m}$. They are regarded as air pollutants from combustion activities such as motor vehicles and industrial processes. According to the World Health Organization [19], the 24-h mean standard for $\mathrm{PM}_{10}$ is $50 \mu \mathrm{g} / \mathrm{m}^{3}$. Figure 4 showed the chart generated from the readings of $\mathrm{PM}_{10}$ obtained from the survey compared with the WHO standard for $\mathrm{PM}_{10}$.

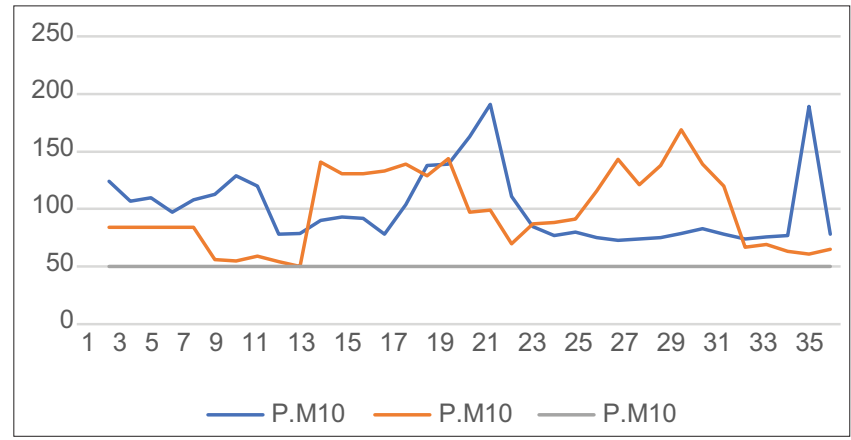

Figure 4: Measurement of particles, $P M_{10}$

The 24-h mean for $\mathrm{PM}_{10}$ was $98.43 \mu \mathrm{g} / \mathrm{m}^{3}$ and $101.06 \mu \mathrm{g} / \mathrm{m}^{3}$ for the residential spaces and office spaces, respectively. In Figure 4, only two residential spaces were the closest to the standard, while the rest for both the office and residential spaces are clearly above the WHO standard for the 24-h mean standard for $\mathrm{PM}_{10}$. The findings of the high presence of $\mathrm{PM}_{2.5}$ and $\mathrm{PM}_{10}$ are replicated in other studies [13]. Whereas, Riediker et al. [20] reported that exposure to high levels of $\mathrm{PM}_{2.5}$ and $\mathrm{PM}_{10}$ can induce heavy breathing and result in cardiovascular problems, mainly among young office workers. 
The air quality measuring device was used to measure the TVOC present in the air in the buildings surveyed. TVOC or TVOCs is a term used to describe a group of compounds that are present in emissions or ambient air. The chemical properties of TVOCs vary widely. They are essentially a complex mixture of potentially hundreds of low-level VOCs. They impact the air quality of places such as hospitals, office buildings, and schools. TVOCs can exist indoor as a result of fabrics, paints, glues, varnishes, disinfectants, smoke, floor wax, and soaps. Figure 5 showed the 24-h measurement of the TVOC, TVOC for the residential and office spaces. The 24-h mean for the TVOC was $0.26 \mathrm{ppm}$ and $0.29 \mathrm{ppm}$ for the residential spaces and office spaces, respectively. This is lower than the maximum limit of 3 ppm for TVOC.

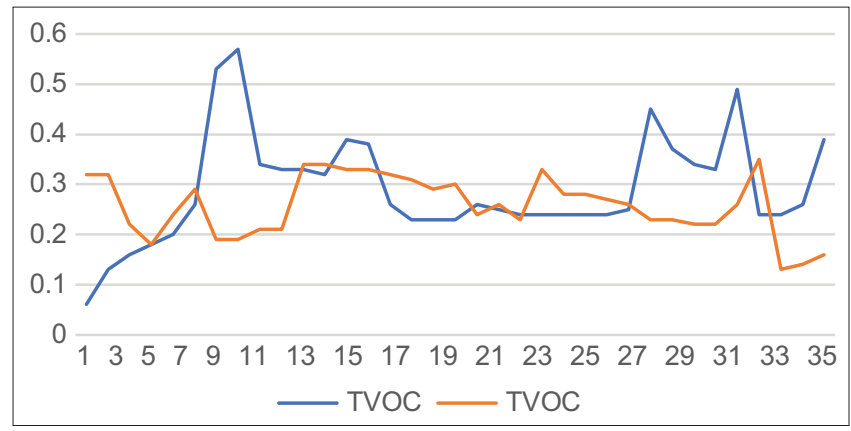

Figure 5: Measurement of total volatile organic compounds (TVOC), TVOC

The standard for formaldehyde $(\mathrm{HCHO})$ in the work place is 0.75 parts formaldehyde per million parts of air (0.75 ppm) over 8-h [21]. The readings for formaldehyde $(\mathrm{HCHO})$ were given by the air quality monitor in $\mathrm{mg} / \mathrm{m}^{3}$, so the formula was used to convert the readings to the unit ppm, which is shown in Equation 2.

$$
X_{p p m}=\frac{Y m g / m^{3} \times 24.25}{30.031 \mathrm{~g} / \mathrm{mol}}
$$

After the readings for formaldehyde in both offices and residential spaces were converted, a chart was derived, as shown in Figure 6.

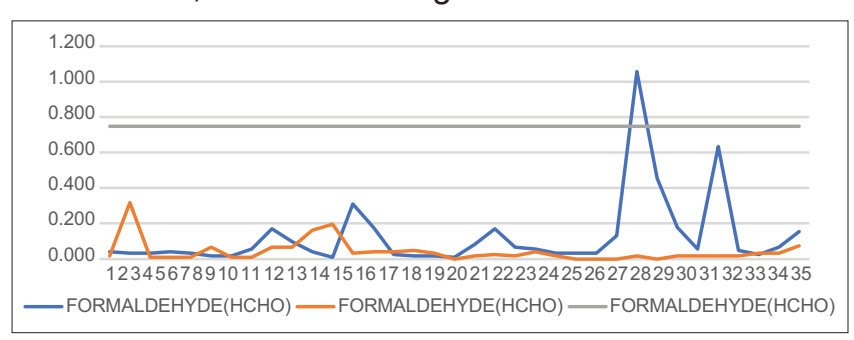

Figure 6: Measurement for formaldehyde ( $\mathrm{HCHO})$

The 24-h mean for the $\mathrm{HCHO}$ was $0.16 \mathrm{ppm}$ and $0.05 \mathrm{ppm}$ for the residential spaces and office spaces, respectively. This is lower than the maximum limit of $0.75 \mathrm{ppm}$ for TVOC. The chart in Figure 6 showed that the formaldehyde $(\mathrm{HCHO})$ in about the $27^{\text {th }}$ office space was above the standard and that of the $31^{\text {st }}$ office space was close to exceeding the standard.
However, the other readings for both the residential and office spaces were below the standard which is safe. The temperature readings for both the residential and office spaces were taken as well during the survey with the same Air Quality Monitor. It is expected that the average room temperature of every space should be $23^{\circ} \mathrm{C}$. The $24-\mathrm{h}$ mean for the room temperature was $25.41^{\circ} \mathrm{C}$ and $24.06^{\circ} \mathrm{C}$ for the residential spaces and office spaces, respectively. This is higher than the average room temperature of $23^{\circ} \mathrm{C}$.

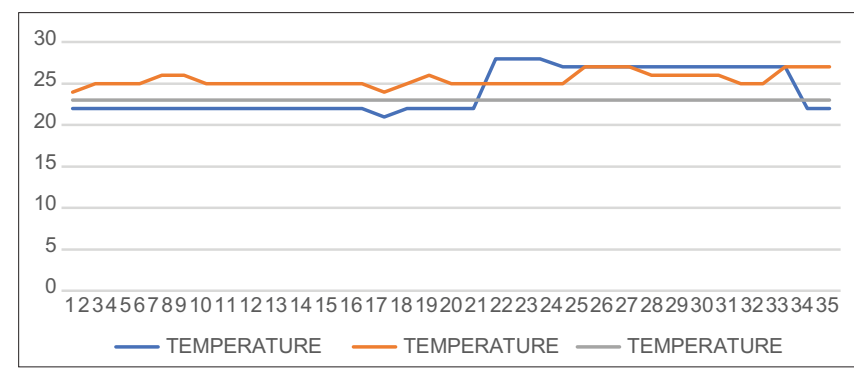

Figure 7: Measurement of temperature $\left(23^{\circ} \mathrm{C}\right)$ in the building spaces

In Figure 7 , the office spaces, the $1^{\text {st }}$ to $19^{\text {th }}$ office had room temperature below $23^{\circ} \mathrm{C}$ while the other readings both for the residential and office spaces exceeded the average temperature. For the spaces below the room temperature, there may be an indirect adverse implication on the health of the occupants, especially those with cardiorespiratory diseases. With lower temperature, there is more probability of having wet elements which can result into molds which can affect the health of the occupants. In addition, for those spaces, the huge cost is been accrued on energy utilization. With other spaces in residential and office spaces having their room temperature higher than the ideal room temperature standard of $23^{\circ} \mathrm{C}$, they may find it hard to concentrate due to the high temperature considering the high temperate region of Northern Nigeria. While discussing the ideal room temperature, humidity plays an important role in the thermal comfort of occupants. For the office and residential spaces that were surveyed, the readings for relative humidity were obtained. It is expected that the indoor relative humidity should be at $50 \%$. On this basis, the chart in Figure 8 was formed using the readings of the relative humidity obtained from the residential and office spaces surveyed.

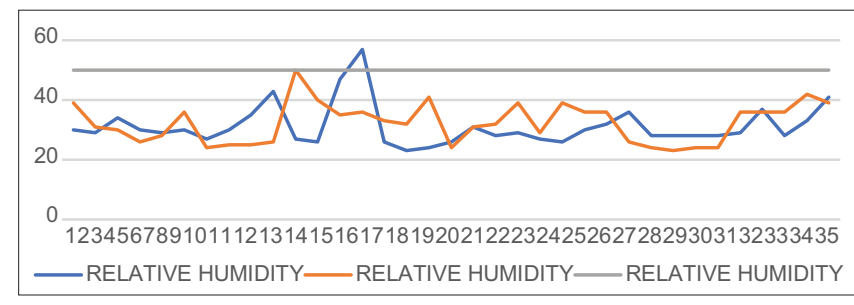

Figure 8: Measurement for relative humidity in the building spaces

From Figure 8, most of the building spaces in residential and office spaces had low humidity below the standard of $50 \%$. The $24-\mathrm{h}$ mean for the relative humidity was $32.37 \%$ and $31.20 \%$ for the residential and office spaces. With low humidity, this means that 
it would result in high temperatures within the building spaces. The low humidity can cause discomfort among occupants and make them susceptible to cold/flu and other respiratory problems due to the dryness that occurs in the mucous membrane in their nose and throat. The presence of dry air from the low humidity can also affect the eyes, the skin, and create an environment that is virus-friendly.

\section{Conclusion and Recommendations}

The study assessed SBS due to indoor pollution in residential and office buildings. The study showed that the symptoms associated with the SBS from indoor pollution were mainly cold or flu, burning or nasal itching, and muscle pain in arm or hand. The indoor conditions that may contribute to SBS in the residential and office spaces were mainly lighting conditions, headroom in the building, and position of windows. Further analysis showed that there was a significant relationship between occupants' having headaches, fever, and dizziness with indoor conditions such as the use of air conditioning systems and increased noise level. Moreover, there was a significant relationship between drowsiness and lighting conditions and nausea and size of the room spaces. In addition, the implication of SBS from indoor pollution on residential and office space occupants was manly increased maintenance, dizziness, and depression/breakdown. The study showed that there were significant implications of SBS which leads to stress, can reduce productivity, can affect concentration, can lead to the need to change residential/office space, reduced commitment, and increase the need for maintenance works. The measurement of the indoor pollutants contributing to the SBS among residential and office space occupants showed that PM2.5 and PM10 were above the average mean standard, while the TVOC and $\mathrm{HCHO}$ were within the average standard recommended by the WHO. The study recommended that;

- $\quad$ Air cleaning through the use of mechanical filters or electronic air cleaners can be a helpful solution in capturing and control of small particles. Alternatively, high-performance filters can be installed to capture smaller particles as well as respirable particles but are expensive to install and operate

- $\quad$ Building owners/developers can focus on smart buildings that integrate air quality detectors in web-based systems that can alert occupants on the air pollution levels and ways to minimize the source of air pollution

- $\quad$ The filters in air conditioning systems should be consistently cleaned to allow good airflow indoors - $\quad$ There is a need to keep air pollution such as burning of wood, smoking, or other combustion to a minimum indoors to avoid issues of SBS In light of the major symptoms associated with SBS, attention should be duly given to the working environment by employers by providing proper ventilation, both natural and artificial, in the right proportions. Building occupants should practice airing of spaces by opening the windows periodically to air out the homes and office spaces to improve air quality There is a need for increased awareness of SBS through seminars and public lectures that pertain to information about SBS, prevention and the associated effects on individuals

Subsequently, further research in this line can be carried out using qualitative analysis which will involve engaging the respondents orally to obtain primary data. Industrial areas and factories can also be considered as the study area. This study focused on the 24-h mean of measuring the air pollutants, future studies can be focused on measuring a year mean and compared with the international standards. The scope on the study area can also be increased from Kaduna State to other states that have high air pollution such as Lagos and Rivers State.

\section{References}

1. Jerome N. Application of Maslow's hierarchy of need theory; impacts and implications on organizational culture, human resource and employee's performance. Int J Bus Manage Invent. 2013;2(3):39-45. Available from: https://www.pdfs.semanticscholar.org/b0bc/ c8ca45193eaf700350a8ac2ddfc09a093be8.pdf. [Last accessed on 2019 Sep 21].

2. Evans GW, McCoy JM. When buildings don't work: The role of architecture in human health. J Environ Psychol. 1998;18:85-94.

3. Afolabi A, Tunji-Olayeni $P$, Oyeyipo $O$, Ojelabi R. The socioeconomics of women inclusion in green construction. Constr Econ Build. 2017;17:70-89. Available from: https://www.epress. lib.uts.edu.au/journals/index.php/ajceb/article/view/5344/5858. [Last accessed on 2019 Sep 21]. https://doi.org/10.5130/ajceb. v17i1.5344

4. Tunji-Olayeni P, Afolabi A, Okpalamoka O. Survey datase on occupational hazards on construction sites. Data Brief. 2018;18:1365-71. Available from: https://www.sciencedirect. com/science/article/pii/S2352340918303792. [Last accessed on 2019 Sep 21]. https://doi.org/10.1016/j.dib.2018.04.028

5. Kukec A, Dovjak M. Prevention and control of sick building syndrome (SBS). Part 1: Identification of risk factors. Int J Sanit Eng Res. 2014;8:16-40. Available from: https:// www.journal.institut-isi.si/prevention-and-control-ofsick-building-syndrome-sbs-part-1-identification-of-riskfactors/?download=15467. [Last accessed on 2019 Sep 21]. https://doi.org/10.1007/978-3-642-17919-8_30

6. Sarafisa $P$, Sotiriadou $K$, Dallas D, Stavrakakis $P$ Chalaris M. Sick-building syndrome. J Environ Prot Ecol. 2010;11:515-22. Available from: https://www.researchgate. net/publication/262728404_sick-building_syndrome. [Last 
accessed on 2019 Sep 21].

7. Iyagba RA. The Menace of Sick Buildings: A challenge to all for its prevention and treatment. Akoka, Nigeria: University of Lagos Press; 2005. Available from: http://www.196.45.48.50/opendoc. php?sno $=9130 \&$ doctype $=$ pdf $\&$ docname $=$ the - menace-of-sickbuildings:-a-challenge-to-all-for-its-prevention-and-treatment. [Last accessed on 2019 Sep 21].

8. Health Effects Institute. State of Global Air 2018. Special Report. Boston, MA: Health Effects Institute; 2018. Available from: https://www.stateofglobalair.org/sites/default/files/soga2018-report.pdf. [Last accessed on 2019 Sep 21].

9. Fotoula PB. The sick building syndrome (SBS). Health Sci J. 2011;5(2):72-3.

10. World Health Organization. WHO Guidelines for Indoor Air Quality: Selected Pollutants. Geneva: World Health Organization; 2010. Available from: http://www.euro.who.int/_data/assets/pdf file/0009/128169/e94535.pdf. [Last accessed on 2019 Sep 21].

11. Joshi SM. The sick building syndrome. Indian J Occup Environ Med. 2008;12(6):1-4. Available from: http://www.ijoem.com/ article. asp? issn $=0019-5278$; year $=2008$; volume $=12$;issue $=2 ;$ s page $=61 ;$ epage $=64 ;$ aulast $=$ joshi. [Last accessed on $2019 \mathrm{Sep}$ 21]. https://doi.org/10.4103/0019-5278.43262

12. Gomzi M, Bobic J. Sick building syndrome: Do we live and work in unhealthy environment? Period Biol. 2009;111(1):7984. Available from: https://www.hrcak.srce.hr/file/56816. [Last accessed on 2019 Sep 21].

13. Zamani M, Jalaludin J, Shaharom N. Indoor air quality and prevalence of sick building syndrome among office workers in two different offices in Selangor. Am J Appl Sci. 2013;10(10):10407. Available from: https://www.pdfs.semanticscholar. org/3304/34a5ad02f6ec7d060203c51c0ab439036b35.pdf. [Last accessed on 2019 Sep 21]. https://doi.org/10.3844/ ajassp.2013.1140.1147

14. World Health Organization. Indoor Air Pollutants: Exposure and Health Effects. EURO Reports and Studies. Geneva: World Health Organization; 1983.

15. Burge S, Hedge A, Wilson S, Bass JH, Robertson A. Sick building syndrome: A study of 4373 office workers. Ann Occup Hyg. 1987;31(4A):493-504.

PMid:3439759

16. Bourbeau J, Brisson C, Allaire S. Prevalence of the sick building syndrome symptoms in office workers before and six months and three years after being exposed to a building with an improved ventilation system. Occup Environ Med. 1997;54(1):49-53. https://doi.org/10.1136/oem.54.1.49 PMid:9072034

17. Wang J, Li J, Zhao C. A Case of Sick Building Syndrome Caused by Incorrect Ventilation Design of the Tight Building. Proceedings of Indoor Air, 490-493; 2002. Available from: http:// www.irbnet.de/daten/iconda/cib7170.pdf. [Last accessed on 2019 Sep 21].

18. Atarodi Z, Karimyan K, Gupta VK, Abbasi M, Moradi M. Evaluation of indoor air quality and its symptoms in office building-a case study of Mashhad, Iran. Data Brief. 2018;20:749. https://doi.org/10.1016/j.dib.2018.07.051 PMid:30105278

19. World Health Organization. WHO Air Quality Guidelines for Particulate Matter, Ozone, Nitrogen Dioxide and Sulfur Dioxide. Global Update 2005. Summary of Risk Assessment; 2006. Available from: https://www.apps.who.int/iris/ bitstream/10665/69477/1/who_sde_phe_oeh_06.02_eng.pdf. [Last accessed on 2019 Sep 21].

20. Riediker M, Cascio WE, Griggs TR, Herbst MC, Bromberg PA. Particulate matter exposure in cars is associated with cardiovascular effects in healthy young men. Am J Respir Crit Care Med. 2004;169(8):934-40. https://doi.org/10.1164/ rccm.200310-1463oc

PMid: 14962820

21. Occupational Safety and Health Administration. Indoor Air Quality in Commercial and Institutional Buildings. Occupational Safety and Health Administration U.S. Department of Labor; 2011. Available from: https://www.osha.gov/publications/3430indoorair-quality-sm.pdf. [Last accessed on 2019 Sep 21]. https://doi. org/10.1201/9781315269603-43 